\title{
Titae
}

$35(2019) 435-457$

\section{Sławomir Jeziorski}

Wyższe Seminarium Duchowne w Rzeszowie

Uniwersytet Papieski Jana Pawła II w Krakowie

sjeziorski@gmail.com, ORCID: 0000-0001-8710-5259

\section{LITURGIA A PERCEPCJA I PRZEŻYWANIE CZASU W DOBIE POSTMODERNIZMU}

\section{Liturgy, Perception and Experiencing Time in the Postmodern World}

Relacja pomiędzy liturgią a czasem jest głęboko zakorzeniona w naturze celebracji. Liturgia wydarza się w czasie, ale $\mathrm{z}$ drugiej strony ma ona zdolność interpretowania czasu i jego percepcji. W świecie, który bywa nazywany epoką prędkości, nie tylko liturgia potrzebuje czasu, ale także czas potrzebuje liturgii. Ta wzajem- rok liturgiczny na relacja między czasem a liturgią jest treścią niniejszego artykułu, w którym zostanie zaprezentowany zarówno wymiar antropologiczno-fenomenologiczny jak i teologiczny celebracji liturgicznej oraz jej wkład w kształtowanie doświadczenia czasu. 
The relationship between time and liturgy is profoundly rooted in the nature of celebration itself. Liturgy occurs in time but, on the other hand, it is able to interpret time and its perception. In our world - undeniably an age of speed - it is not only liturgy which needs time: Time needs liturgy as well. It is this reciprocal relationship between time and liturgy which is the focus of this article. It presents both the anthropological-phenomenological and theological dimensions of the liturgical celebration, and liturgy's contribution to shaping the whole experience of time.

postmodernism, culture, time, sacred time, liturgy, rite, Liturgy of the Hours, liturgical year

Liturgia i czas są ze sobą nierozerwalnie związane. Celebracja liturgiczna rozciąga się w czasie, ma swój początek i koniec, a między tymi granicznymi momentami istnieje określony przedział czasowy, w którym trwa akcja liturgiczna. Czas więc, obok przestrzeni, jest istotnym faktorem, który pozwala wspólnocie gromadzić się na celebracji. Wspólnota potrzebuje czasu niczym macierzy, w której może celebrować liturgię. Niepełna byłaby jednak teza, która ograniczataby się tylko do takiego jednostronnego ujęcia zagadnienia. Istotnie, o ile czas jest elementem koniecznym dla doświadczenia liturgicznego, o tyle także możliwa jest relacja odwrotna: celebracja liturgiczna może oddziaływać na percepcję i doświadczenie czasu tych, którzy biorą w niej udział. Celebracja posiada taką funkcję zarówno gdy bierzemy pod uwagę jej formę rytualną, jak i treść teologiczną. Innymi słowy, liturgia nie tylko potrzebuje czasu, ale ona sama posiada zdolność interpretowania go. Ta wzajemna relacja między czasem a liturgią w doświadczeniu człowieka będzie treścią niniejszego opracowania. 
Pierwszym krokiem, który pozwoli wejść w prezentowane zagadnienie, będzie zarysowanie pewnego sposobu myślenia i przeżywania czasu, właściwego współczesnej kulturze, która coraz bardziej problematycznym czyni udział w celebracji liturgicznej. Naświetlenie pewnych tendencji myślenia właściwych epoce postmodernizmu otworzy perspektywę dla bardziej adekwatnego rozwinięcia przedstawianego problemu. W dalszej części artykułu zostaną więc uwzględnione dwa aspekty celebracji liturgicznej, które w podobnej mierze mogą przyczyniać się do zmiany w percepcji czasu. Pierwszy z nich skupi się na antropologicznym wymiarze liturgii, opisując relację czasu do akcji rytualnej, w której wyraża się doświadczenie człowieka. Drugi z kolei sięgnie teologicznego wymiaru, przedstawiając treść celebracji, która dostępna jest przez wiarę i jako taka powinna stawać się punktem odniesienia dla człowieka wierzącego w jego sposobie przeżywania czasu.

\section{Czas i liturgia We wSPÓ£CZeSnej Kulturze}

Jednym z najczęstszych zmagań, którą współczesny człowiek toczy niemal każdego dnia jest walka o czas ${ }^{1}$. Styl życia, który wydaje się w dużej mierze charakteryzować aktualną kulturę może być ujęty w kategoriach współzawodnictwa, zdobywania i posiadania. W takim kontekście czas jawi się jako jedno $\mathrm{z}$ upragnionych trofeów owych dążeń. W sposób zwięzły wyraził to jeden $\mathrm{z}$ analityków wspomnianego fenomenu: „tworzymy niejako pościg za chwila, tracimy czas aby zaoszczędzić czas, aby nagromadzić pełne arsenały akcesoriów, metod i ułatwień, które pozwoliłyby nam mieć więcej czasu"2. Główny akcent zdaje się padać raczej na pragnienie posiadania niż na sam czas. Owo „mieć” jest

1 Por. Pareydt, „L'homme”, 8-12.

2 Mazza, „Tempi della vita”, 4. 
bowiem aspiracją człowieka na tyle globalną ${ }^{3}$ że pretenduje także do posiadania czasu, co w konsekwencji czyni w człowieku niejako przymus swoistego pościgu za nim. Wobec takiej mentalności nie powinien dziwić fakt, że nasza epoka bywa nazywana „epoką prędkości”, w której życie codzienne przyspiesza tym bardziej, im bardziej pragnienie posiadania zderza się z bezradnością wobec uciekającego czasu ${ }^{4}$. Sytuacja wydaje się jeszcze bardziej warta refleksji, kiedy zdamy sobie sprawę, że opisana wyżej tendencja dotyczy nie tylko pojedynczych osób, ale także całych społeczeństw.

Szukając pierwszego zrozumienia opisanego fenomenu, zatrzymajmy się na chwilę nad aktualnym kontekstem kulturowym. To on w jakiś sposób jest glebą, na której rodzi się owa „epoka prędkości”. Pragnienie posiadania w ogólności, skonkretyzowane także wobec czasu, można ująć jako niewątpliwy przejaw i zarazem owoc mentalności ponowoczesnej, która charakteryzuje współczesną epokę. Jedną z cech właściwych takiej filozofii jest fakt, że człowiek postrzega siebie jako protagonistę swoich działań i kreatora swojego życia. Skoro współczesne osiągnięcia nauk i techniki budzą przeświadczenie, że rodzaj ludzki jest w stanie niejako panować nad prawami natury, to na bazie tego przekonania osoba postrzega również siebie jako kogoś zdolnego do zapanowania nad własnym życiem. Rodzi to przekonanie, że podmiot jest zdolny wykreować, zrealizować i zabezpieczyć swoją egzystencję. W konsekwencji w człowieku otwiera się pragnienie nieograniczonej wolności i nieskrępowanej kreatywności, która mogłaby wyjść poza wszelkie z góry narzucone porządki, włączając $w$ to również czasoprzestrzeń. Taka wolność i kreatywność zakłada posiadanie wszelkich

3 Por. Spinks, The Worship Mall, XV-XXIV.

4 Mówimy w tym kontekście o czasie egzystencjalnym w odróżnieniu od czasu fizycznego. Taki czas egzystencjalny możemy nazwać czasem doświadczalnym, albo percepcją czasu przez człowieka. Por. Bonaccorso, Il rito e l'altro, 46-59.

5 Por. Cescon, Liturgia nel postmoderno, 19-23. 
„surowców”, dzięki którym człowiek może zrealizować to, czego pragnie.

To schematyczne scharakteryzowanie sposobu myślenia człowieka ponowoczesnego daje pewną bazę, aby opisać właściwą dla niego percepcję czasu. Człowiek-kreator nie widzi już czasu jako okresu trwania, w którym może spełniać swoją codzienną aktywność, ale jako potencjalny przedmiot posiadania. Uprzedmiotowiony czas jest postrzegany jako „swego rodzaju materiał, którym posługujemy się dla naszych celów, mierząc i przycinając go według pomysłów, które chcemy zrealizować" ${ }^{\prime \prime}$. Czas w taki sposób zostaje sprowadzony do swego rodzaju „surowca” potrzebnego do zrealizowania własnego pomysłu na życie. Takie instrumentalne potraktowanie czasu implikuje roszczenie zapanowania nad nim w taki sposób, aby mógł on stać się przydatny, użyteczny i produktywny. Doświadczenie jednak nieuchronnie pokazuje, że sam upływ czasu wymyka się ludzkiej chęci dominacji nad nim i podporządkowania go sobie. Na styku tych dwóch elementów: pragnienia posiadania i instrumentalizacji czasu oraz doświadczenia bezradności wobec jego upływu, rodzi się napięcie, a w ślad za nim to nieustanne przyspieszenie, które czyni współczesną epokę "cywilizacją prędkości”.

W takiej sytuacji momentami najbardziej narażonymi na zepchnięcie na margines ludzkiego życia są te, które z punktu widzenia użyteczności zdają się najbardziej nieopłacalne. Mowa o takich chwilach aktywności człowieka, które nie dają bezpośrednich, wymiernych rezultatów bądź których rezultaty ciężko jest obliczyć i wykalkulować. Właśnie takie „bezużyteczne” i „nieopłacalne” momenty są pierwszymi ofiarami „epoki prędkości”. W tym gronie „wykluczonych z życia" znajduje się chrześcijańska liturgia i celebracja jako taka. Wskazane aktywności, naznaczone jakością cza-

Rizzi, „Tempo e liturgia”, 318.

Por. Mazza, „Tempi della vita”, 6. 
su świętego ${ }^{8}$, są chwilami trwania, które z ekonomicznego punktu widzenia są mało użyteczne, o ile nawet nie należałoby jednoznacznie określić ich jako wręcz bezużytecznych. Logika dominowania, posiadania, zdobywania i użyteczności - właściwa dla czasu zwyczajnego, przeżywanego według logiki konsumpcyjnej - jest całkowicie obca momentom rytualnym?

Jest więc czymś naturalnym, że człowiek ponowoczesny pierwszych „oszczędności czasowych” będzie szukał w czasie świętym czy - bardziej konkretnie - liturgicznym ${ }^{10}$, eliminując momenty celebracyjne ze swojego życia. „Oszczędności” takie są jednak tylko pozorne. Porzucenie celebracji liturgicznych nie rozwiązuje bowiem istotnej kwestii zależności od czasu. Człowiek bowiem nie zyskuje w ten sposób dodatkowych godzin, zmienia jedynie przeznaczenie tych, które posiada, oddając je na użytek tego, co przynosi wymierne korzyści. Paradoksalnie taka postawa prowadzi do zniewolenia codzienności logiką ekonomii, użyteczności i produktywności. W konsekwencji zniewolenie to dotyka samego człowieka, który zostaje zamknięty w ograniczonej mentalności materializmu praktycznego. W niej czas jeszcze bardziej zdaje się przyspieszać i uciekać człowiekowi.

W tym momencie dochodzimy do tego, co wydaje się jednym z wyzwań Kościoła i ludzi wierzących we współczesnym świecie: chodzi o odkrycie na nowo liturgii jako aktywność ludzkiej, która będąc przeżywana w czasie, ma zdolność nadania mu nowej jakości. Innymi słowy, wyzwanie to polega na wprowadzeniu człowieka w takie doświadczenie liturgiczne, dzięki któremu może on otrzymać nową, uwolnioną z niewoli konsumpcjonizmu i przymusu pogoni, percepcje

8 Mowa tutaj o czasie celebracji liturgicznej, ale w analogiczny sposób możemy mówić o czasie modlitwy osobistej, który posiada podobną charakterystykę jeśli chodzi o kryterium użyteczności.

9 Por. Mazza, „Tempi della vita”, 6.

10 W ten sposób nazywamy czas, w którym celebrowana jest liturgia, jako moment spotkania z sacrum. 
czasu. Takie doświadczenie rodzi się z faktu, że czas święty, a konkretniej czas celebracji liturgicznej, staje się momentem zdystansowania się od tego, co jedynie pragmatyczne i opłacalne, a więc pojmowane według logiki zysku. Wobec tego czas liturgiczny jest - być może - jedyną możliwością zatrzymania „chorobliwej koncentracji perspektywy czasu i zasobów, którymi dusimy naszą codzienność" ${ }^{11}$.

Wobec tak ujętego zagadnienia, tym bardziej nagląca wydaje się być potrzeba przybliżenia wzajemnej relacji pomiędzy celebracją liturgiczną a czasem i jego percepcją w kontekście doświadczenia człowieka. Na wskazaną relację spróbujemy spojrzeć na dwóch płaszczyznach, które przynależą do samej natury liturgii: fenomenologiczno-antropologicznej, a więc rytualnej, dotyczącej formy celebracji, oraz teologicznej, która odnosi się do treści rytu.

\section{WYMIAR ANTROPOLOGICZNY LITURGII W JEJ RELACJI DO CZASU}

Do natury liturgii, obok modlitw wyrażanych słowami, należą także postawy, gesty, symbole i znaki, które w całości tworzą ryt ${ }^{12}$. Nawet więcej, sama liturgia z punktu widzenia antropologicznego jest rytem czy - w sposób nieco bliższy ujęciu teologicznemu - rytualnym sposobem uobecnienia zbawczego wydarzenia ${ }^{13}$. Tak rozumiana liturgia jest ak-

11 Mazza, „Tempi della vita”, 7.

12 Ten aspekt liturgii wydaje się być sprowadzony nieco na drugi plan w refleksji posoborowej, co wynikało z chęci przezwyciężenia sztywnego rubrycyzmu, z którym ryt był utożsamiany. Obecnie daje się zauważyć pewien powrót i dowartościowanie rytu jako elementu konstytutywnego liturgii. W niniejszym artykule nie zajmujemy się jednak szerzej rytem jako takim w całej jego złożoności. Ograniczymy się do tego aspektu, który dotyczy jego odniesienia do czasu i jako taki wchodzi w główny tok rozumowania niniejszego artykułu. Więcej na temat samego rytu oraz rytualności. Por. Bonaccorso, Rito; Bonaccorso, Il rito e l'altro; Terrin, Il rito.

13 Por. Tagliaferri, „Ripetizione e pericolo rituale”, 93. 
cją symboliczną, która trwa w czasie. Czas jest więc, obok przestrzeni, istotnym wymiarem celebracji. $Z$ drugiej strony ryt, który można zdefiniować jako „sposób, według którego wspólnota postrzega świat" ${ }^{14}$, posiada zdolność reinterpretowania tegoż świata. W konsekwencji, reinterpretując rozumienie świata, celebracja rytualna niesie w sobie potencjał nadawania sensu i modelowania percepcji upływającego czasu.

Podwójne odniesienie akcji rytualnej do czasu, o którym mowa, wydaje się o tyle bardziej kluczowe, o ile przekracza ono jedynie teoretyczne dywagacje na omawiany temat. Celebracja bowiem nie tylko opowiada o czasie, ale poprzez swój dynamizm wprowadza uczestników w konkretne doświadczenie egzystencjalne: doświadczenie, które „,nie ogranicza się tylko do myślenia o czasie, ale go modeluje i modyfikuje według swojego upodobania" ${ }^{15}$. W ten sposób stajemy wobec dwóch wymiarów relacji liturgii do czasu.

\subsection{Ryt jako szczególny moment czasu}

Ryt, należąc do dziedziny aktywności ludzkich, jest akcją symboliczną rozciągniętą w konkretnym przedziale czasowym: ma swój początek, obejmuje określony moment trwania jak również posiada konkretny punkt zakończenia. Jego cechą charakterystyczną jest więc trwanie. O ile jednak pod względem trwania czynność liturgiczna ma wspólny mianownik z innymi aktywnościami człowieka, o tyle sam charakter tego trwania wykazuje w stosunku do nich istotną różnicę.

Tym, co odróżnia ryt od innych aktywności człowieka jest fakt, że w przypadku akcji symbolicznej to nie człowiek i wspólnota są kreatorami, twórcami działania. Nawet jeśli do nich należy wykonanie rytu, to sama treść i sposób wy-

\footnotetext{
14 Bonaccorso, Rito, 6.

15 Terrin, Il rito, 237.
} 
konania czynności symbolicznych jest im nadany. Ponadto, o ile ryt zawsze jest spełniany przez konkretną wspólnotę, o tyle nie dokonuje się to według tempa przez nią narzucanego. Podczas celebracji wspólnota uczestnicząca w wydarzeniu poddaje się rytowi, który podąża za swoim własnym porządkiem czasowym, mając właściwy sobie wewnętrzny $\mathrm{rytm}^{16}$. Miarą trwania celebracji jest więc sama architektura rytu: przynależące do niego gesty, słowa oraz porządek, według którego akcja rytualna powinna być wykonana. Z punktu widzenia trwania czynności rytualnej jej czas jest niezależny nie tylko od zegara, ale również od człowieka, a w konsekwencji od wspólnoty, która go wykonuje ${ }^{17}$. Ta podwójna niezależność jest istotnym elementem charakteryzującym celebrację liturgiczną w jej aspekcie antropologicznym.

Biorąc pod uwagę ten charakter rytu, można stwierdzić, że sama dynamika celebracji ze swej natury stawia człowieka wobec pewnego rodzaju wyzwania: polega ono na pozostawieniu swojej zwyczajnej aktywności, której to człowiek nadaje rytm, i wzięciu udziału w wydarzeniu, którego trwanie nie jest określone ani przez uczestników, ani przez wyznaczone z góry godziny. Rezygnacja z osobistych roszczeń dotyczących zarówno tempa celebracji, jak i jej formy jest istotnym warunkiem autentycznego uczestnictwa w liturgii. Co ważne, warunek ten stawiany jest przez samą naturę celebracji.

Ten szczególny moment czasu, w którym dokonuje się czynność liturgiczna, z natury swojej prowokuje więc człowieka do wyjścia poza mentalność właściwą dla „epoki prędkości”. Jest to swoiste wyzwanie aby przezwyciężyć logikę konsumpcji, użyteczności i opłacalności. Celebracji liturgicznej nie sposób bowiem sprowadzić do wymienionych faktorów ekonomicznych, które pozwoliłyby poddać ją wła-

16 Por. Girardi, „Il rito e il tempo”, 141.

17 Por. Terrin, Il rito, 239. 
dzy człowieka. Wszelkie szukanie oszczędności, użyteczności czy uleganie pokusie pośpiechu odebrałoby celebracji to, co należy do jej istoty - ową podwójną niezależność, która wzywa człowieka ku transcendencji.

Wymagania, które stawia przed człowiekiem sam charakter aktywności kultycznej nie tylko prowokuje tych, którzy stoją wobec decyzji wzięcia udziału w rycie, ale także poddaje próbie cierpliwość tych, którzy już są uczestnikami wydarzenia. Kto bowiem nie jest cierpliwy, kto nie ma wewnętrznej wolności, aby wejść w czas święty i nadzwyczajny, aby „rozgościć się” w logice darmowości, ten nie może pretendować do tego, by celebrować jakiekolwiek wydarzenie w sposób rytualny ${ }^{18}$. Oczywiście taki człowiek może znajdować się w czasie i miejscu, w którym odbywa się celebracja, jednak bez wewnętrznej zgody zostaje czlowiekiem-poza-czasem-liturgii. Innymi słowy, ten, kto nie poddaje się wydarzeniu liturgicznemu i nie daje się pociągnąć właściwej logice liturgii, ten sam nie przyznaje sobie prawa do prawdziwego świętowania i wyklucza się z niego.

W konsekwencji wewnętrzna zgoda na uczestnictwo w rycie w sposób darmowy i bezinteresowny jest koniecznym warunkiem pełnego przeżycia wydarzenia liturgicznego. Darmowość i bezinteresowność, o których mowa, nie są jakimiś elementami czysto teoretycznymi. Postawy te nabierają konkretnego kształtu i wyrażają się w radości, w brater-

18 Ten podział na czas święty-rytualny i czas zwyczajny pozwala głębiej zrozumieć problem używania telefonów komórkowych w czasie celebracji. Jeśli natura rytu wymaga separacji czasu nadzwyczajnego czy świątecznego od czasu zwyczajnego i konsumpcyjnego, to kwestia wyłączania telefonów nie jest kwestią jedynie dobrego wychowania i wyeliminowania ewentualnych dźwięków, które mogłyby zagłuszyć przebieg celebracji. W takim wypadku wystarczyłoby wyciszenie urządzeń. Wyłączenie natomiast jest konkretnym aktem, który jest konieczny, aby wyjść poza czas zwyczajny, zostawić codzienność, nie być do niej przyzywanym poprzez otrzymywane wiadomości i powiadomienia, ale by w całości zaangażować się i poddać rytmowi celebracji i kształtującej mocy rytu. Por. Borello, „Il rito”, 18-21. 
skim byciu we wspólnocie, we współdzieleniu czasu, a także innych dóbr materialnych, które konkretny ryt przewiduje. W takim doświadczeniu współdzielenie ma więc prymat nad zdobywaniem, darmowość nad użytecznością, relacje osobowe nad indywidualnym zyskiem. Biorąc pod uwage zarysowaną charakterystykę celebracji można stwierdzić, że wydarzenie rytualne nie jest jedynie odmienną formą wyrażania zwyczajnej, konsumpcyjnej i nastawionej na zysk ludzkiej aktywności. Taka aktywność jest całkowicie przeciwna logice ekonomii i niesprowadzalna do niej, jeśli chodzi o dynamikę przeżywania czasu ${ }^{19}$.

Rytm, według którego spełnia się celebracja nie tylko wymaga od człowieka konkretnej postawy, ale sam również oddziałuje na uczestników wydarzenia liturgicznego ${ }^{20}$. Celebracja liturgiczna posiada bowiem zdolność kształtowania i modelowania życia tych, którzy biorą w niej udział. Uczestnik liturgii, poddając się rytmowi celebracji, zostaje wprowadzony w doświadczenie, które uczy go wyznaczać tempo swojej egzystencji według rytmu celebracji. W ten sposób dochodzimy do drugiego elementu relacji liturgii do czasu w jej wymiarze antropologicznym.

19 Biorąc pod uwagę tą charakterystykę rytu bardziej zrozumiałe wydaje się nieporozumienie, a nawet swego rodzaju ignorancja obecna coraz częściej na płaszczyźnie działania duszpasterskiego, w którym liturgię i życie liturgiczne Kościoła próbuje się zaoferować współczesnemu człowiekowi prezentując je w logice użyteczności i opłacalności, jako swego rodzaju usługę czy towar w markecie duchowości. Jak wynika z przedstawionej treści, w ten sposób zostaje jednak zagubiony istotny wymiar liturgii: jej darmowość, bezużyteczność i bezinteresowność. Czy biorąc pod uwage naturę celebracji, nie byłoby bardziej odpowiednim prowokowanie człowieka do wyjścia poza logikę wolnego rynku niż oferowanie mu liturgii jako jednego z wielu towarów, który ma być bardziej konkurencyjnych niż te oferowane przez współczesną kulturę?

20 Por. O'Donnell, Remembering the Future, 4. 


\subsection{Liturgia jako wydarzenie porządkujące czas zwyczajny}

Czas celebracji nie odrywa jej uczestników od codziennej egzystencji, nie wycina pewnej „oazy” wokół nich i nie odcina ich od własnej historiii ${ }^{21}$. Nawet jeśli dokonuje się jasna i konkretna separacja między czasem zwyczajnym i czasem świętym, to jej celem nie jest izolacja człowieka od rzeczywistości jego życia. O ile wcześniej czas rytualny sam w sobie zostal scharakteryzowany jako moment oddzielony od codzienności, o tyle teraz możemy zobaczyć jego znaczenie dla percepcji codziennego czasu zwyczajnego.

Wyjście z czasu zwyczajnego i wejście w czas celebracji dokonuje się w tym celu, aby w świetle wydarzenia rytualnego, z dystansem i z właściwą logiką, spojrzeć na bieg życia, w którym toczy się codzienna aktywność uczestników liturgii. Akcja rytualna w takim znaczeniu może być porównana do swego rodzaju lustra, w którym człowiek postrzega, interpretuje i modeluje zwyczajny czas swojej aktywności. Spojrzenie w owo lustro wymaga jednak zatrzymania, stąd aktywność rytualna może być nazwana „momentem ekstazy czasowej, która jest w stanie odkupić czas zwyczajny od jego zwyczajności i wprowadzić w niego pauzę"22. Taki moment pauzy-ekstazy zrywa jednorodność czasu zwyczajnego. Pauza ta nie jest jednak celem samym w sobie. Staje się ona momentem, w którym możliwe jest spojrzenie z dystansem na osobistą aktywność. To z kolei pozwala „skomponować na nowo w sposób bardziej wyrazisty"23 działalność, do której człowiek wróci po celebracji.

Kompozycja czasu zwyczajnego, o której mowa, dotyczy z jednej strony rytmu życia, z drugiej zaś - hierarchii ważności i priorytetów nadawanych obowiązkom. Mówiąc o rytmie życia, odwołujemy się do samej natury rytu, którego

\footnotetext{
21 Mazza, „Tempi della vita”, 6.

22 Terrin, Il rito, 238.

23 Terrin, Il rito, 238.
} 
rytm jest niezależny zarówno od uczestników celebracji, jak i od zegara. Taki moment akcji rytualnej, rozumiany jako pewna przerwa w codziennej aktywności, może stać się swego rodzaju antidotum na ciągłe przyspieszanie czasu zwyczajnego, którego treścią są codzienne zadania realizowane według logiki ekonomii. Czas celebracji jest wprowadzeniem pewnego opóźnienia temporalnego, chwilą zatrzymania i zwolnienia tempa. Zatrzymanie to winno być postrzegane raczej jako środek niż cel sam w sobie. Ryt zatrzymuje człowieka nie dla samego zatrzymania, ale po to, by w tym momencie pauzy wprowadzić go w inny, transcendentny wymiar egzystencji. W ten sposób dochodzimy do drugiego elementu poddanego wspomnianej kompozycji.

Moment pauzy-ekstazy czasowej, oprócz wprowadzenia nowego rytmu w życie człowieka, jest również swego rodzaju porządkowaniem treści egzystencji. Celebracja ma zdolność tworzenia w jej uczestnikach swego rodzaju wewnętrznej wolności i dystansu do czysto utylitarystycznych aktywności. Na poziomie antropologicznym liturgia wprowadza w życie człowieka takie elementy, jak: wolność, darmowość, bezinteresowność, radość, wspólnotowość i dzielenie. One, wraz z rytmicznością i zwolnieniem tempa, tworzą doświadczenie, w którego świetle możliwe staje się przemyślenie na nowo celu i hierarchii obecnej w codziennej aktywności ${ }^{24}$.

Warty podkreślenia jest ów wymiar doświadczalny. W celebracji nie chodzi bowiem tylko o wiedzę i intelektualne dywagacje na opisywane tematy. Uczestnictwo w celebracji nie jest przecież jedynie teoretyczną lekcją o czasie. Celebracja jest wydarzeniem, które oddziałuje na uczestników poprzez postawy, gesty znaki i słowa. Komunikacja treści odbywa się więc w sposób przeżyciowy. W takim doświadczeniu angażowana jest cała osoba wraz z jej cielesnością, emocjonalnością i duchowością. Czas celebracji jest więc momentem formującym jej uczestników, którzy po powro-

24 Por. Girardi, „Il rito e il tempo”, 143. 
cie do codzienności mogą w nowy sposób przeżywać swoją aktywność zarówno pod względem rytmu, jak i priorytetów.

$\mathrm{O}$ ile już na poziomie rytualnym celebracja prowokuje pewien rodzaj doświadczenia czasu, o tyle ten wymiar strukturalny musi zostać dopełniony elementem treściowym. Ryt bowiem zawsze opowiada i w sposób symboliczny wyraża pewną historię lub wydarzenie ${ }^{25}$. Ta jego cecha otwiera nas na teologiczny wymiar celebracji. W kontekście liturgii chrześcijańskiej mówimy tutaj o treści Objawienia, którą akcja rytualna „opowiada” poprzez słowa, symbole, gesty i znaki. To właśnie w tej treści odsłania się sens czasu, który daje człowiekowi wierzącemu ostatecznie uzasadnienie przeżywania własnej historii jako odkupionej. Tak otwiera się horyzont perspektywy teologicznej, która dopełnia prezentowane zagadnienie.

\section{WyMiaR TEOLOGICZNY LITURGII \\ I JEGO WPEYW NA PERCEPCJĘ CZASU}

Liturgia chrześcijańska z jednej strony jest wydarzeniem trwającym w czasie i jako taka zawiera w sobie konkretną treść, która zostaje wyrażona poprzez ryt. $\mathrm{Z}$ drugiej strony udział w celebracji liturgicznej implikuje nowe, chrześcijańskie spojrzenie na czas codzienności. Te dwa wymiary, analogiczne do tego, co zostało zarysowane na poziomie antropologiczno-fenomenologicznym rytu, zostaną teraz zaprezentowane.

\subsection{Celebracja misterium jako wydarzenie dokonujące się w czasie}

Podejmując temat treści, która wyraża się poprzez ryt w liturgii chrześcijańskiej dochodzimy do Osoby-wyda-

25 Por. Maggiani, „Rito/riti”, 1671. 
rzenia Jezusa Chrystusa, który jest obecny w swoim Kościele „Zwłaszcza w czynnościach liturgicznych”(KL 7). To stwierdzenie Konstytucji o liturgii Sacrosanctum Concilium w sposób precyzyjny wskazuje dynamiczny wymiar liturgii, która jest czynnością rytualną, gdy chodzi o formę, a zarazem obecnością misterium Jezusa Chrystusa, gdy chodzi o jej treść ${ }^{26}$.

Dokument soborowy rysuje jednocześnie szerszy kontekst przytoczonego wyrażenia, ukazując w ten sposób, że obecność Jezusa Chrystusa nie stanowi arbitralnego aktu, ale jest uobecnieniem Jego misterium paschalnego, w którym swój punkt kulminacyjny osiąga cała historia zbawienia (KL 5-8). Wydarzenie paschalne, będąc manifestacją miłości Ojca, który nie dopuścił, aby Jego Syn pozostał w otchłani (por. Dz 2,24-28; Ps 16,8-10), w sposób konkretny dotyka również problematyki czasu. Jak trafnie ujął to kard. J. Ratzinger, zmartwychwstanie Jezusa to moment „definitywnego, rzeczywistego wejścia Boga w historię" 27 . Wskrzeszając swojego Syna, Ojciec objawił samego siebie jako Boga życia, który „zachował władzę nad historią" ${ }^{28}$. Teofania paschalna wprowadza więc nowy sposób interpretacji historii. W jej świetle czas nie jest już bezdusznym, nieustannie uciekającym przeciwnikiem człowieka. Władzę nad czasem i historią posiada miłujący Bóg. To On doprowadził historię Jezusa Chrystusa do pełni, a teraz, poprzez liturgię, prowadzi do tego samego celu cały Lud Boży.

Celebrując opisane wydarzenie paschalne, wierzący zostają dotknięci tą samą konkretną miłością Ojca, która wskrzesiła Chrystusa z martwych, obdarzając Go pełnią życia. Tak jak zmartwychwstanie Chrystusa jest objawieniem odwiecznej, działającej miłości Ojca panującego nad historią i czasem, tak samo celebracja misterium paschalnego

26 Por. Marsilli, „Tempo litrgico”, 233.

27 Ratzinger, Teologia liturgii, 226.

28 Ratzinger, Teologia liturgii, 226. 
w liturgii „jest teraźniejszym skutecznym znakiem tej samej wiecznej rzeczywistości" ${ }^{29}$.

W ten sposób wydarzenie liturgiczne, w którym uczestniczą chrześcijanie staje się odblaskiem wieczności, w nim czas zostaje przemieniony $\mathrm{w}$ wydarzenie, $\mathrm{w}$ epifanię królestwa Bożego ${ }^{30}$. Ten odblask wieczności dostępny przez wiarę, darowany jest wierzącym jako przedsmak i zadatek pełni, do której zdążają (KL 8).Z kolei to doświadczenie prowadzi do przemienionego spojrzenia na sens czasu i historii. Nowa perspektywa zmartwychwstania Chrystusa dzięki celebracji staje się także perspektywą życia Ludu Bożego. W konsekwencji ludzka egzystencja w Jezusie Chrystusie nie jest już wyścigiem z czasem, ale momentem spotykania się z wieczną miłością; czas nie jest już materiałem, który człowiek miałby wykorzystać dla realizacji własnych celów, ale darem, w którym może przeżywać życie jako niepowtarzalną misję powierzoną mu przez Ojca do wykonania.

Celebrowane misterium Chrystusa nadaje nowe znaczenie także cechom akcji rytualnej, które wcześniej zostały zaprezentowane. Darmowość, bezinteresowność, wspóldzielenie właściwe dla czynności rytualnych, w świetle misterium śmierci i zmartwychwstania stają się elementami wyrażającymi dynamikę życia Jezusa Chrystusa. W konsekwencji przejście od logiki konsumpcji do logiki miłości nie jest już jedynie prowokacją samej akcji rytualnej i działaniem człowieka, ale udziałem $\mathrm{w}$ dynamice paschalnego misterium Jezusa Chrystusa. Chrześcijanie w zwycięstwie Chrystusa widzą już swoje zwycięstwo nad biegnącym bez ustanku czasem, który wraz z całym stworzeniem jest we władzy miłującego Ojca. Dla wyznawców Zmartwychwstałego czas już nie dąży do końca, ale do swojej pełni, nie jest on przeciwnikiem człowieka, ale momentem spotkania miłującego Ojca. Stąd moment celebracji, poprzez wyjście z lo-

30 Por. Taft, La liturgia, 412. 
giki ekonomii i wejście w logikę darmowości i bezinteresowności, już jest swego rodzaju interioryzacją i uwiecznieniem tego, co zostało zrealizowane w życiu, śmierci i zmartwychwstaniu Jezusa Chrystusa.

Podsumowując, uczestnictwo w celebracji jest spotkaniem z Ojcem, który objawia swoją władzę nad czasem poprzez wskrzeszenie swojego Syna i pragnie wprowadzić w to doświadczenie wszystkich wierzących. Czas celebracji liturgicznej w swoim wiecznym dzisiaj (hodie) ma zdolność nadać nowy rytm i miarę egzystencji odkupionej ${ }^{31}$. Przedstawiona teologiczna treść celebracji liturgicznej znajduje konkretne formy, poprzez które Kościół chce pomóc człowiekowi wierzącemu przeżywać jego egzystencję w nowym stylu, właściwym człowiekowi wierzącemu. W ten sposób możemy przejść do ostatniego elementu charakteryzującego relację liturgii i czasu, w którym spojrzymy, jaki rytm przeżywania czasu codziennej egzystencji człowieka proponuje liturgia.

\subsection{Czas jako moment przeżywania misterium celebrowanego}

Misterium paschalne, które uobecnia się w liturgii i w którym uczestniczą wierzący, otwiera nowy horyzont życia. Aby pomóc wiernym w prawdziwie chrześcijańskim przeżywaniu egzystencji, Kościół poprzez liturgię rozciąga celebrację misterium Chrystusa w czasie, modelując w ten sposób jego percepcję. Mówiąc o liturgii w jej relacji do czasu, możemy wyróżnić dwa cykle celebracji: cykl dzienny, którego kształt tworzy liturgia godzin, oraz cykl roczny - nazywany rokiem liturgicznym. To one w głównej mierze pozwalają w sposób rytmiczny i ciągły przeżywać chrześcijańską egzystencję według dynamiki paschalnej.

Sobór Watykański II, podejmując w Konstytucji o liturgii Sacrosanctum Concilium temat liturgii godzin, stwier-

31 Triacca, „Tempo e liturgia”, 1996. 
dził: „Zgodnie ze starożytną tradycją chrześcijańską liturgia godzin jest tak ułożona, aby przez uwielbienie Boga uświęcała wszystkie pory dnia i nocy" (KL 84). Ojcowie soborowi, odwołując się do tradycji, zwrócili uwagę na dzienny rytm modlitwy Kościoła. Jej celem - jak stwierdza dokument - jest uświęcenie wszystkich pór dnia i nocy. Ogólne wprowadzenie do Liturgii godzin idzie jednak o krok dalej w doprecyzowaniu sensu celebracji. Dokument od ogólnego wymiaru uświęcenia pór dnia i nocy przechodzi do ludzkiej egzystencji, mówiąc że celem liturgii godzin jest uświęcenie dnia i całej ludzkiej działalności ${ }^{32}$. Nie tylko sam bieg czasu, ale także ludzka działalność, która ma miejsce w ciągu dnia, nabiera nowego, symbolicznego znaczenia ${ }^{33}$.

W ten sposób rytualny czas modlitwy modeluje codzienną aktywność człowieka tak, że już nie on sam jest pionierem i prekursorem swoich działań. Wierzący, poprzez celebrację liturgii godzin, otrzymuje takie spojrzenie na życie, dzięki któremu nie pretenduje już do tego, aby kreować je w sposób autonomiczny. Momenty celebracji, szczególnie poranek i wieczór, które uznawane są za kluczowe momenty całego dnia liturgicznego (KL 89a), pozwalają przeżywać upływ czasu jako dar, dzięki któremu można wziąć udział w misterium Chrystusa i który można wyrazić w swojej aktywności. W ten sposób codzienne sprawowanie liturgii godzin pozwala człowiekowi doświadczać czasu w sposób odkupiony; czasu, który nie jest już wrogiem człowieka, ale jego sprzymierzeńcem; czasu, który nie ucieka, ale prowadzi człowieka do pełni misterium paschalnego.

Oprócz cyklu dziennego liturgia Kościoła posiada także cykl roczny, zwany rokiem liturgicznym. O ile jest czymś naturalnym, że człowiek przeżywa swoje życie według kalen-

32 Ogólne wprowadzenie do Liturgii godzin, 11.

33 Celem tego artykułu nie jest obszerny wykład na temat Liturgii Godzin, a jedynie zarysowanie pewnych linii teologicznych, które wpisują się w treść niniejszego artykułu. Więcej na temat samej Liturgii Godzin można znaleźć m.in. w: Liturgia uświęcenia czasu. 
darza cywilnego, o tyle udział w celebracjach liturgicznych, świętach chrześcijańskich pozwala wierzącym ten zwyczajny czas przeżywać jako czas święty, jako epifanię Boga. Sobór Watykański II w konstytucji Sacrosanctum Concilium wyraził teologiczny sens roku liturgicznego:

Z biegiem roku Kościół odsłania całe misterium Chrystusa, począwszy od Wcielenia i Narodzenia aż do Wniebowstąpienia, do dnia Zesłania Ducha Świętego oraz oczekiwania błogosławionej nadziei i przyjścia Pańskiego. W ten sposób obchodząc misteria Odkupienia, Kościół otwiera bogactwa zbawczych czynów i zasług swojego Pana, tak że one uobecniają się niejako w każdym czasie, aby wierni zetknęli się z nimi i dostąpili łaski zbawienia (KL 102).

W tym przypadku nie mówimy więc już o celebracjach związanych z godzinami dnia, ale z tymi, które rozciągają się na całoroczny obchód. Tekst soborowy odsłania nowy wymiar każdego roku. Nie jest to już tylko czas zwyczajnej ludzkiej aktywności, która pociągałaby za sobą walkę o czas i pościg za nim. Logika „epoki prędkości” zostaje więc przezwyciężona. Dla człowieka wierzącego bieg roku jest czasem, w którym odsłania się całe misterium Chrystusa. Poprzez udział w uroczystościach człowiek wierzący otrzymuje całkowicie nową wizję upływającego czasu: jest on „żyjącym symbolem wieczności” ${ }^{34}$ otoczonym obecnością Ojca. Bezradność wobec czasu nie jest już więc udręką człowieka, ale doświadczeniem misterium nieuchwytnego Boga, którego podobnie jak czasu, nie da się posiąść. Można Go jedynie poznawać i kontemplować w Jego darmowej obecności, bez pretendowania do tego, aby Go uchwycić, przywłaszczyć i wykorzystać.

Przeżywanie misterium paschalnego Jezusa Chrystusa w rytmie liturgii godzin oraz roku liturgicznego ma zdol-

34 Casel, „Die Überwindung”, 9. 
ność nadać chrześcijańskiemu życiu jeszcze jeden istotny element. Dzięki celebracji może zostać przezwyciężony dualizm między czasem świętym i czasem świeckim. O ile ciągle wiążące jest rozróżnienie na czas rytualny i czas życia codziennego, o tyle w świetle wiary nie można pierwszego utożsamiać z czasem świętym, drugiego natomiast z czasem świeckim. Liturgia uświadamia wierzącym, że są uczestnikami historii zbawienia, która realizuje się w codzienności życia. Stąd dla chrześcijanina, który swoje życie przeżywa $\mathrm{w}$ rytmie liturgii, cała egzystencja jest udziałem w historii zbawienia, uczestnictwem w niej w czasie rytualnym, podczas celebracji, i wyrażaniem jej w czasie codziennym, podczas swojej zwyczajnej aktywności ${ }^{35}$. W ten sposób człowiek zaczyna żyć jakby pulsem misterium Jezusa Chrystusa, w którym - na kształt krwiobiegu w ludzkim organizmie - momenty celebracji i codziennej aktywności na przemian się dopełniają i uzupełniają. Celebracja, niczym skurcz serca, jest momentem dotlenienia egzystencji mocą Ducha Świętego, aby później Jego życie mogło objawić się w całym organizmie powszedniej aktywności człowieka wierzącego.

\section{ZAKOŃCZENIE}

Relacja liturgii do czasu może być badana na wiele sposobów. W niniejszym artykule został przedstawiony taki, który pozwala zobaczyć to wzajemne oddziaływanie w kontekście współczesnej kultury. W tym kontekście zostały zaprezentowane aspekty liturgii, które we właściwy sobie sposób wchodzą w relację z czasem. W wymiarze antropologiczno-fenomenologicznym podkreślono niezależność celebracji od czasu. Ryt posiada bowiem swój własny rytm, który musi zostać uszanowany. Dzięki niemu celebracja wymyka się logice pośpiechu. W opisie teologicznego wymiaru celebracji

35 Por. Salenson, „Le temps liturgique”, 24. 
przywołane zostało paschalne wydarzenie Chrystusa, które przekracza czas, a zarazem jest treścią liturgii chrześcijańskiej.

Zarówno w jednym, jak i w drugim przypadku wydawało się słuszne, aby nie poprzestawać jedynie na przedstawieniu samego momentu celebracyjnego, ale rozwinąć także te idee prezentujące związek i wpływ celebracji na przeżywanie codziennego czasu.

Takie pojednanie czasu świętego i czasu zwyczajnego może sprawić, że współczesny człowiek będzie w sposób bardziej konkretny doświadczał mocy odkupienia. Sięga ono przecież także tego istotnego wymiaru ludzkiego życia, jakim jest czas: on także został odkupiony i świetle wiary nie jest nieprzyjacielem i konkurentem, ale sprzymierzeńcem człowieka w przeżywaniu jego egzystencji.

\section{BIBLIOGRAFIA}

\section{Dokumenty Kościoła}

Sobór Watykański II, Konstytucja o liturgii Sacrosanctum Concilium. Tekst tacińsko-polski (Poznań: Pallottinum 2008). Ogólne wprowadzenie do Liturgii godzin (Pallottinum: Poznań 1992)

\section{Studia}

Bargellini E., „Il tempo liturgico attuazione della salvezza nella storia dell'uomo", Vita Monastica 154 (1983) 7-18.

Bonaccorso G., Il rito e l'altro: la liturgia come tempo, linguaggio e azione (Citta del Vaticano: Libreria Editrice Vaticana 2001).

Bonaccorso G., Rito (Padova: Messaggero 2015).

Borello S., „Il rito: la percezione della durata”, Rivista di Pastorale Liturgica 325 (2017) 18-21. 
Casel O., „Die Überwindung der Zeit im Kreuze Christi”, $L i$ turgie und Mönchtum 5 (1950) 5-10.

Cescon B., La liturgia nel postmoderno (Città del Vaticano: Libreria Editrice Vaticana 2012).

De Clerck P., „Les rythmes de vie et les ordonnances de la messe", La Maison-Dieu 231 (2002) 47-65.

Girardi L., „Il rito e il tempo”, Celebrare il mistero di Cristo III: La celebrazione e i suoi linguaggi (red. L'Asocciazione Professori di Liturgia) (Roma: CLV-Edizioni Liturgiche 2012) 139-163.

Liturgia uświęcenia czasu - rozumieć, aby lepiej uczestniczyć. Wyktad liturgii godzin (red. J. Hadalski) (Poznań: Hlondianum 2017).

Maggiani S., ,Rito/Riti”,Liturgia (red. D. Sartore - A.M. Triacca - C. Cibien) (Cinisello Balsamo: San Paolo 2001) 1666-1675.

MarsilliS., ,Tempo liturgico”, Rivista Liturgica 57 (1970) 207-235. Mazza G., „Tempi della vita e tempo rituale”, Rivista di Pastorale Liturgica 325 (2017) 4-7.

O'Donnell E., Remembering the Future. The Experience of Time in Jewish and Christian Liturgy (Collegeville, MN: Liturgical Press 2015).

Pareydt L., „L'homme et le temps: «Danser dans les chaînes»”, La Maison-Dieu 231 (2002) 7-17.

Ratzinger J., Teologia liturgii (Opera Omnia 11; Lublin: Wydawnictwo KUL 2012).

Rizzi A., „Tempo e liturgia”, Parola, Spirito e Vita 36 (1997) 317-328.

Salenson Ch., „Le temps liturgique à l'épreuve de la fluidité du temps", La Maison-Dieu 231 (2002) 19-35.

Schoos A., „L'existence chrétienne au rythme du temps”, $L a$ Maison-Dieu 231 (2002) 37-46.

Spinks B.D., The Worship Mall. Contemporary Responses to Contemporary Culture (London: SPCK 2010).

Taft R., La liturgia delle ore in oriente ed in occidente. Le origini dell'ufficio e il suo significato per oggi (Roma: Lipa 2001). 
Taft R., Ponad wschodem i zachodem. Problemy rozumienia liturgii (Kraków: Wydawnictwo M 2014).

Tagliaferri R., „Ripetizione e pericolo rituale”, Celebrare il mistero di Cristo III: La celebrazione e i suoi linguaggi (red. L'Asocciazione Professori di Liturgia) (Roma: CLV-Edizioni Liturgiche 2012) 87-136.

Terrin A.N., Il rito: antropologia e fenomenologia della ritualità (Brescia: Morcellina 2015).

Triacca A.M., „Tempo e liturgia”, Liturgia (red. D. Sartore A.M. Triacca - C. Cibien) (Cinisello Balsamo: San Paolo 2001) $1987-2001$.

Ks. SŁawomir Jeziorski, prezbiter diecezji rzeszowskiej, doktor nauk teologicznych w zakresie liturgiki Papieskiego Ateneum Św. Anzelma w Rzymie (2017), wykładowca liturgiki w Wyższym Seminarium Duchownym w Rzeszowie oraz katecheta w Katolickim Liceum Ogólnokształcącym Sióstr Prezentek w Rzeszowie. 
